\title{
Az IBD sebészete
}

| Lestár Béla dr.

Magyar Honvédség Egészségügyi Központ, II. sz. Sebészet, Budapest

Correspondence: lestar52@freemail.hu

Az egyre hatékonyabb gasztroenterológiai gyógyszeres kezelés, biológiai szerek széles körben történő elterjedése ellenére a sebészeti beavatkozások továbbra is nélkülözhetetlen terápiás eszközök maradnak a gyulladásos bélbetegség kezelésében. A javuló gyógyszeres kezelés hatására a colitis ulcerosa miatt végzett mütétek száma csökkent, addig a Crohn-betegségnél ezt nem lehet elmondani. Colitis ulcerosa sikeres mütéte teljes "gyógyulást" tud elérni, addig ez Crohn-betegségben nem igaz. Colitis ulcerosa esetén a totál proctocolectomia, perinealis ilealis rezervoár- (pouch) képzés, ileoanalis anastomosissal az analis kontinencia megfelelő szinten megörizhető. Crohn-betegségnél vékonybél-érintettség esetén ún. „takarékos” technikák, stricturaplasztikák, szük reszekciók lettek jellemzőek. Vastagbél Crohn esetén szabadabb reszekciós elvek érvényesülnek, de a rectum megkímélését szem előtt kell tartani, gondolva arra, hogy ileorectalis anastomosis készítésére is esély maradjon. Analis elváltozások kezelésében szintén mértéktartó sebészi elvek érvényesülnek. Szétesett, funkcióját vesztett analis csatorna esetén azonban végleges stoma a választandó eljárás.

KULCSSZAVAK: gyulladásos bélbetegség, colitis ulcerisa, Crohn-betegség, sebészet

\section{Surgery of IBD}

Gastroenterological medical treatment is more and more effective but contrary to the wide spread of biologic the surgical interventions remain indispensable therapeutic approach in the treatment of inflammatory bowel disease. Due to effect of improving medical treatment, the number of surgical procedures for colitis ulcerosa is decreasing but this cannot be stated for Crohn's disease. Successful surgery for colitis ulcerosa may reach complete recovery, but it is not true for Crohn's disease. After total proctocolectomy, perineal ileal pouch, with ileoanal anastomosis can preserve the fecal continence on acceptable level. At Crohn's disease with small bowel involvement the "sparing" surgical technique, stricture plasty and limited resection become typical. At Crohn's disease with large intestine involvement more liberal resection become accepted but preservation of the rectum, has to keep in mind to have a chance to perform ileorectal anastomosis. At the treatment of anal pathology, moderate surgical activity is characteristic. Anal sphincter apparatus without function may indicate to perform definitive stoma.

KEYWORDS: inflammatory bowel disease, ulcerative colitis; Crohn's disease; suregry

\section{Bevezetés}

A gyulladásos bélbetegségnek három fő csoportja van. Colitis ulcerosa, vastagbél fekélyes gyulladása, amely föleg a nyálkahártyát érinti. Longitudinális terjedést mutat. Crohn-betegség a teljes emésztőrendszeren előfordulhat, transmuralis betegség. Predilekciós helye az ileocoecalis bélszakasz. Intermedier colitis szövettanilag is nehezen meghatározható betegség, nehezen elkülöníthető a Crohn-betegségtől vagy a colitis ulcerosatól (1).

A gyulladásos bélbetegségek hazai előfordulásáról kevés adat származik, de becslések szerint kb. 25000 IBD-s beteg van Magyarországon. Ezeknek 47\%-a Crohn-beteg, 40\%-a colitis ulcerosás, 13\%-a nem meghatározott gyulladásos bélbetegség (2). A betegség kezelésében elsődleges a gasztroenterológusok által beállított gyógyszeres kezelés. Csak a gyógyszeres kezelés kudarca után jön számításba a sebészeti beavatkozás. Ma egyre hatékonyabb gyógyszerek állnak rendelkezésre, különösen az utóbbi két évtizedben bevezetett biológiai kezelésekkel van kedvező tapasztalat. Korábban a Crohn-betegek 50-80\%-a életük folyamán mútétre került, a colitis ulcerosás betegek $30 \%$-ánál kellett colectomiát végezni. Hatékonyabb kezelés hatására a Crohnbetegeknél a mútéti arány néhány közlés alapján akár 
40\%-ra is csökkenthetö. Legtöbb szerző szerint azonban a alkalmas a beteg arra, akkor pouchképzés is elvégezhető. Crohn-betegeknek legalább a fele továbbra is mútétre fog kerülni. Az adatok összehasonlítása nehéz, mert a követés idők nagyon különbözők. A colitis ulcerosás betegeknél a colitiseknél ez a szám 13\% körül van (3-6).

\section{A colitis ulcerosa sebészi kezelése}

A colitis ulcerosás betegeknél a mútéti arány 15\%, a legöbbjjük elektív mútét, sürgős beavatkozás csak minoritás.

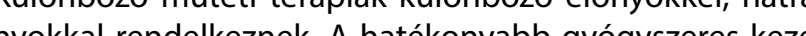
nyokkal rendelkeznek. A hatékonyabb gyógyszeres kezefokozatosan csökken, addig a Crohn-betegség miatt végzett mútétek száma stagnál.

Sürgős beavatkozások indikációi colitis ulcerosa kezelésében

A klinikai tünetek súlyos romlása, véres széklet gyako ürítése, láz, szapora szívmüködés, anémia, gyulladáso paraméterek emelkedése, colondisztenzió, hasdisztenzió hasi fájdalom (7). Ezek mind mütét mellett szólnak. llyen akut esetekben is gyógyszeres kezeléssel kell megpróbálkozni, ez leggyakrabban akár 80\%-os sikerrel is járhat. Ha javulás nem következik be néhány napon belül (48-96 óra) vagy tovább erősödnek a tünetek, a mútét elkerülhetetlen. A toxikus megacolon meghatározásában segít a radiológiai kép megtekintése, kriterium általában a colon transve sum $6 \mathrm{~cm}$-es tágassága. A toxikus megacolon kezelésében is gyógyszeres kezelessel kell megpróbálkozni de, ha további dilatáció vagy perforáció vagy keringési instabilitás lép fel, akut mútetet kell vegezni. Toxikus megacolonnál a perforációt elóre megjósolni nehéz, ha az elơfordul, akkor a klinikai kimenetel igen rossz, 30-60\%-os mortalitássa kell számolni. Ugyanigy, ha hemodinamikai instabilitás vagy többszervi elégtelenség áll fenn, a mortalitás akár $70 \%$ fölé is emelkedhet $(8,9,10,11)$.

\section{Mütéti lehetősége}

Nagyon elesett állapotú betegnél, akinél a mútéti teherbíró képesség minimális, akut esetben tehermentesító ileostoma felhelyezése is szóba jöhet, de ez végleges megoldást nem ad.

Megnyugtatóbb megoldás sürgőss esetekben is a károsodott, fekélyes vastagbél eltávolítása, vég-ileostoma kialakításával. A mútét lényege, hogy colectomát végzünk, de a rectumcsonkot visszahagyjuk, ezzel elkeruljuk a kismebeavatkozás elégséges. A rectumcsonk lezárása áltzá ban nem javasolt legiobb megoldás a rectumcsonkat symphisis felett nyák-fisztulának kialakítani $(12,13,14)$. A posztoperatív szakban a rectumcsonk gyógyszerekke öblíthetố, így a gyulladás csökkenthető. De előfordult má néhány esetben, hogy a visszahagyott rectumcsonkbó profúz vérzés indult, így a rectumcsonkot is sürgősségge el kellett távolítani. A mútét jó oldala még az, hogy ha gyulladásos folyamat lezajlása után a visszahagyott ra tumcsonkot választott idóben el lehet távolítani, és ha adt vissza, akkor a pouchképzés, mint második mútét lényegesen nehezebb, mint amikor a rectumcsonk a helyén van. A rectumcsonk a kismedencei felszabadítást segíti, a preparálásnak irányt mutatva. Ha a rectumcsonk hiányzik, férfiaknál a hólyag, nőknél hüvely, uterus a vékonybelekkel egyútt a sacrumra szivósan rátapadhat. Késöbb ennek

A colitis ulcerosa elektív mütétei

Indikáció

A gyógyszeres kezelés kudarca esetén leggyakrabban elektiv mútétet kell végezni. A mútéti időpont meghatároközösen kell kialakítani A döntésben különböző aktivitási indexek használata segíthet. Főleg a betegség klinikai és kevésbé az endoszkópos paramétereinek összessége adja meg az aktivitási indexet. Aktivitási index alkalmazásával a gyógyszeres kezelés hatékonysága index alkalmazásával a itélhetōo, és a mútétre kerülő betegek állapota összehasonlítható. Gyermekkorban a fejlődés elmaradása már önmagában indikáció (15). A colitis ulcerosa fennállása 10 év esetén 2\%-ban, 20 év esetén $8 \%$-ban, 30 év esetén $18 \%$-ban predesztinál karcinóma kialakulására. Ezért nem lehet elégszer hangsúlyozni az ellenörző kolonoszkópiák szükségességét elvégezni a sorozatos szövettani biopsziával egybekötött kolonoszkópiát. Karcinóma esetén mútét abszolút indikált displasia eseteben azonban ellentmondásosak a vélemények. A high grade displasia és a displasia szövettömörüléssel együtt (DALM) múteti indikációt jelent. Alacsony grádisu displasiák esetén is sok sebész mutet mellett foglal allást megelózve a késôbbi problemmákat. Ha a vastagbelen szüküet van, a biopsziak rendszerint nem mervadóak, a szükület ténye szintén mütéti indikációt jelent $(16,17,18)$. A szükület azt is jelentheti, hogy nem colitis ulcerosával, hanem Crohnbetegséggel állunk szemben (19). Mútéti indikációt jelent még, ha a colitis ulcerosa sulyos extraintestinalis manifesztációkkal jár együtt: arthritis, uveitis. De sajnos a szklerotizáló cholangitisen, ankyloticus spondylarthrosison, sacroileitisen a colectomia nem javít. A bőrrelváltozások, mint pl. az ra adott válasza nem egyértelmú $(20,21)$.

\section{Sebészeti lehetőségek}

A colitis ulcerosa elektív mútétére több fajta megoldás nyík előnyökkel, illetve hátrányokkal. A sebészeknek ezeket kell mérlegelniük a mútét megválasztásakor. Fel kell mérni azt, hogy az eltávolítandó colonban van-e karcinóma és a beteg milyen egyéb betegségekkel rendelkezik. Elsődleges cél eltávolítani a beteg vastagbelet, végbelet, eliminálni a rák lehetőségét, helyreállítani a normális bélmüködést. Azt azonban tudni kell, hogy a sebészeti beavatkozásnak morbiditása, sőt mortalitása is van és a stoma-viselés az várásai is is jelentösenthatja. A mútéti megoldást a beteg el-
Ha a rectumcsonk eltávolított, csak az analis csatorna mazását gasztônterógus belgyógyásznak és a seb́sznek Az endoszkóposoknak elóírt, hogy milyen sứrúséggel kel várásai is jelentösen befolyásoljąk, amelyet a beteg,
Totál proctocolectomia vég ileostomával ez továbbra is standard mútéti megoldás colitis ulcerosa esetén (22). A mútét során a beteg teljes vastagbele, végbele eltávo-
lításra kerül. Az életminőséget ez jó és rossz irányban is litásra kerül. Az életminooséget ez jó és rossz irányban is befolyásolhatja. Funckionálisan is kedvezo lehet a totá proctolectomia, vég-ileostoma olyan esetekben, amikor a gyakori veres szekkleturitest a beteg gyenge sphincter apparátussal visszatartani nem tudja. A stomaviselés kedvezobb, mint egy perlanalis dermatitistokozó inkontinencia. volt problémája úgy az ileostoma negativan befolyásolja . Annak ellenére hogy a t

Ancón vé-ileomentes. végleges megoldásnak túnik, nem problématunk is alátámaszt, az esetek negyedében stoma-revizióra fog szorulni a beteg 10 éves követés alatt. Stenosis, visszasüllyedés, stoma-prolapsus, súlyos peristomális dermatitis tud kialakulni. Vékonybél-obstrukció is gyakran megfigyelt jelenség. A gáttáji disszekció szexuális és hólyagdiszfunkciót tud okozni arról nem is beszélve, hogy a gáttáii sebzés sok esetben elhúzódó gyógyulást tud mutatni. Meglepő, hogy amikor a resztorativ mútét életminőségi eredményét hasonlítják össze a végállású ileostomiával, a kettő között nincs nagy különbség (23).

Az ileostomának a legnagyobb hátránya a colostomával szemben az, hogy a béltartalom ürülése folyamatos. Kock a 60-as évek második felében kontinens ileostomát dolgozott ki, amelynek az az elve, hogy a vékonybélből egy rezervoárt képez a vékonybél perisztaltikus nyomását csökkentve és a kivezetés pedig egy invaginált bélszelep (24). A bélszelep megakadályozza a béltartalom akaratlan ürülését. A pouchbol a széklet urülèse csak úgy lehetséges, ha egy drencsōvön keresztül a pouchot leengedjük. Ezze a mütettel a folyamatos béltartalomcsorgás megszünik, beteg "kontinensse" valik. A beavatkozas hatrannya az, hogy a szelep elégséges funkcioja nem mindig megfeleló, az esetek 30\%-aban reoperacióra kerûl sor. Ezt a mútéti típus ma már csak néhány helyen végzik a világban, a rezervoá

Colectomia után néhány esetben elektív mútétként megengedett, ha a rectumcsonk elfogadható állapotban van, ileorectalis anastomosist késziteni (26). Ez a mútét a Crohn-betegek mütéte, de colitis ulcerosa esetén is szigorú feltetelek mellett elvégezhetó. De a nemzetközi tanumanyok az bizonyitjâk, hogy még kezdetben sikeres mútét eseten is az esetek $5 \%$-aban a beavatkozás kudarcot vall hosszabb távon (27). Napjainkban az altalánosan elfogarott rum ettávoltása után periceasis ilealis pou a colón és a mútét lényege, hogy a Kock elgondolása szerint kialakítot alacsony nyomású rezervoárt az analis csatornára rávarrva az analis kontinencia megőrizhető A mútétet Parks és $N$ cols közölte le előszzör 1978-ban (27). Az idők folyamán az $S^{\prime \prime}$ alakú rezervoárt az egyszerübben kialakított J" rezervoár váltotta fel a kézi ileonalis anastomosis napjainkban pedig kettős gépi technikával készül a legtöbb esetben (28). Az elmúlt 30 év a mútéti eljárás alkalmasságát egyértelmúen bizonyította. A perioperatív mortalitás $1 \%$ alatt van, a morbiditás, amely ileoanalis anastomosis elégte- lenséget jelent legtöbb esetben, 5-10\% $(29,30,31)$. A tehermentesító ileostoma a varratelégtelenséget nem, de a perinealis szepszis súlyosságát jelentősen csökkentheti. A vó fiszzôdnényei kozzott kell megemliteni a hüvely felé fertilitás csökkenését. A funkcionális eredmények követtke zök: áltá́ ejszaka. A minor inkontin 4 szekleturtese van nappal, 1-2 amely éjzzaka ár $50 \%$ is lect. Eza ténya betegpal $30 \%$

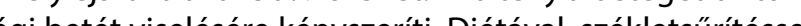

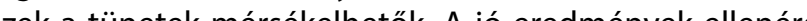
pouchok funkciój hosszú távon annyira romolhat (gyaa pis ścürítés - több mint 10) hogy a pouch eltávolítésra kerül a beteg végleges stomaviselö lesz. A pouch hátrányaként kell megemlíteni, hogy a rezervoár pontosan nem meghatározott ok miatt akár az esetek 30-40\%-ában gyulladásba kerül (32). A gyulladás érintheti magát a poucho (pouchitis), de bizonyos esetekben cuffitis lép fel (ez az analis tranzíciós zóna gyulladását jelenti). A tünetek azonosak: görcsös hasi fájdalom, láz, gáttáji fájdalom, gyakori székưrítés. Az esetek döntő többségében antibiotikummal, mint metronidasol vagy ciprofloxacin a tünetek jól ès gyorsan megszüntethetők. Poucheltávolításra ilyen ok

Kérdések a pouchképzés mütéténél Allandóan ismetloodő kérdés, minden beteg alkalmas-e Kor

Rossz anális funkcióval, társbetegségekkel rendelkezó betegek nem alkalmasak erre a mútetre. Olyan eletkort, amely felett a pouchot nem célszerú elkésziteni, nagyon nehez megallapitani, a beteg alkatát is figyelembe kell venni. Azok, a 70 evv folotti idós betegek, aki jelentos súly-

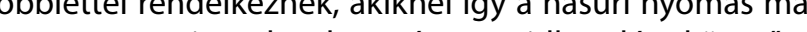
gas, mesentenumuk a hosszú szteroidkezelést kovetoen szakadekonyak, a várható magas szovoódményráta es a Tehermentesitó stoma

Pouchképzésnél az ileoanalis anastomosis kritikus varratsor. A tehermentesítő ileostoma a perinealis szepszis esélect có́ch okozója is lehet. Ezért általánosan megfogalmazható, hogy tehermentesités nélkül pouchot késziteni csak válogatott

aparoszkópos eljárás colitis ulcerosa esetén

Colitis ulcerosa esetén gyakorlatilag minden mútéti eljárás laparoszkóposan elvégezhető. A gyakorlat és az eszközpark fejlődésével a mútéti idő, a nyitott mútéthez képest a papzkópos idő lényegesen lerövidithető volt. A Szegedi Egyetem Sebészeti Klinikája ma már nagy biztonságga ud laparoszkópos úton restoratív proctocolectomiat végezni. A laparoszkópos mútéti eljárás a betegek számára vonzóbb mint a nagy hasi feltárással történő nyitott mütét (35). Totál proctocolectomiát és az ileoanalis anastomosist laparoszkóposan végzik, míg a pouch kialakitása hasüregen kívül kis metszésböl történik. 


\section{Colitis ulcerosa és a karcinóma}

A közleménynek nem témája a colitis ulcerosa és a karcinóma részletes taglalása. De azt szem előtt kell tartani, hogy 6-7 év jelentős gyulladása után számottevő karcinómás átalakulás esélyével kell számolni. Ezért rendszeres, biop-
sziavétellel egybekötött kolonoszkópia elvégzése alapvető feladat. Ileorectalis anastomosis esetén a rectum tartós gyulladása is kedvez a karcinóma kialakulásának.

\section{Crohn-betegség sebészi kezelése}

A colitis ulcerosa sebészi kezelése a Crohn-betegséghez képest viszonylagosan egyszerübb. A Crohn-betegséget elöemésztőtraktus transmuralis gyulladását jelenti ez a betegség. A betegség elő́fordulhat a teljes emésztörendszerben a szájtól az anusig (37). Az elmúlt évtizedekben könyvtárnyi irodalom jelent meg a betegség etiológiájáról de a ma nyapig a pontos ok nem ismert (38). Mivel a betegség ma tos oka nem ismert, a kezelés is tüneti. Ez vonatkozik úgy a gyógyszeres kezelésre, mint a sebészeti beavatkozásokra. A Crohn-betegség elöfordulása népcsoportonként változó, Európában átlagos a betegség incidenciája 10/100 000, prevalenciája 100/100 000 (39). Magyarországon pontos felmérés nincs, de nagy valószínúséggel a Crohn-betegek száma a tízezret messze meghaladja (2). A Crohn-betegség leggyak-
rabban az ileocolicus bélszakaszt érinti $(50 \%)$, vékonybélérintettség 30\%-ban, vastagbélbetegség 20\%-ban látható. A betegek egynegyedénél perianalis elváltozást is lehet tapasztalni (37). A betegség három csoportja különbozztethetô meg: gyulladásos forma, stenotisaló forma, penetráló forma (40). A terápiás celok elérese erdekében az elsödleges kezelés gyógyszeres, a sebészeti beavatkozás elsosorban a gasztroenterológiai gyógyszeres kezelés kiegeszitésekent, részben a szövődmények (fisztula, tályog) kezelésére jön számításba. Bizonyos szük indikációban a sebészi beavatkozás (pl. term nalis ileum lokalizált érintettsége) a gyógyszeres kezelés alternativájaként szerepelhet a betegség bizonyos stádiumában A Crohn-betegek legalább fele az idốk folyamán mútétre szo rul(41). Sőt mi több, az operált betegek 30-70\%-ánál ismételt mütétre is sor kerül (41). A közölt adatoknak nagy a szórása a
különböző követési idök és a különböző gyógyszeres kezelésu módok miatt van. A sebészeti beavatkozás a gyógyszeres si módok miatt van. A sebészeti beavatkozás a gyógyszeres kezeles kiegészitojének tekintheto, a mai tudásunk szerin elethosszig tartó betegség, kezelésének szerves része a sebeszeti beavatkozas a betegség egyes stadumaiban. Sebeszet

Mütéti indikáció

A sürgősségi (akut) mútéti indikáció az életveszélyes állapot megszüntetése, krónikus mútéti indikáció a beteg roenterológiai belgyógyászati kezelés kudarcát

Sürgősségi mütéti indikáció

Perforáció, masszív vérzés, toxikus colitis vagy megacolon (Crohn-betegségben ritkábban, mint colitis ulcerosában) tályogképződés (hasüreg, perianalis stb.).

\section{Elektív mütéti indikációk}

isztulaképződés tályoggal vagy tályog nélkül, bélelzáró dás, gyógyszeres kezelés hatástalansága, fejlődésben való

Akut mütétek

Az akut mútéteknél szabad perforáció viszonylag ritka indikáció Crohn-betegségben, mert a gyulladásos szövet jelentős barriert képez a perforációs nyilás köré. Vérzés manként erós vérzés is e̋̋fordh for A ér, de alkalnoszikáán nosztikajahoz angio-CT-vizsgalat jelentós segitséget tud netekben terápiás eszközként is szolgálhatnak (44). Toxikus colitis potenciálisan életet veszélyeztető komp kációja a Crohn-betegségnek rendszerint sürgős complimiát tesz szükségessé. Ebben az esetben a legegyszerübb és a legcélravezetőbb megoldás colectomiát végezni ileostomát kialakítani és a rectumcsonkot visszahagyni (45) (lásd colitis ulcerosa fejezetet). A szabad perforáció, szekunder szeptikus sokk igen rossz prognosztikai jel. A bélezáródást, amennyiben gyulladásos elváltozás áll a háttérben, elsősorban konzervatív kezelési móddal, gyógyszeres terápiával kell rendezni. Passzázs megindulása, a gyulladás megszúnése/csökkenése után elektív mútét végzendó. Bizonyított tény, hogy akut mútét esetén több vékonybé kerül eltávolítása, mint elektív beavatkozás során (44).

Elektív mütétek

A beavatkozás célja a beteg életminőségének javitása, amikor ez gasztroenterológiai kezelessel már nem megoldható. Az elektív mútétek idôpontjának meghatározása nehéz feladat, túl korai vagy elkesett mútét a beteg számára elonytelen. Tapinthato Crohn-os rezisztencia, bélkongomerátum esetén amennyiben a tályog vagy a térfoglalás kizárhato, eloször gasztroenterologiai kezeléssel célszeru megpróbálkozni. A gyógyszeres kezelés hatására 5 hónapnál tovább nem szabad várni, mivel az ezt meghaladó váakozás a mủtéti szövődmények arányát megemeli. Tehát célszerú az elektív mútéteket is az indikáció felállitásátó számított 5 hónapon belül elvégezni (46).

A Crohn-betegségben a colorectalis karcinóma a colitis ulcerosához hasonlóan fokozott kockázatot jelent, így kópia kórszövegségfennálás után rendszeres kolonoszzon esetek kritikusak, amikor az orális colonszanosz aborális colonszakasz szükülete miatt nem vizsgálható endoszkóppal.

\section{Mütéti elökészítés}

A Crohn-betegek egy része igen rossz állapotban, lesoványodva, folyadék-, elektrolit- és energiadeficitben kerül mütétre. Ezt a helyzetet mindenképpen orvosolni kell a jobb mútéti eredmény elérése céljából. Ha a mútét sürgetố, kkor is a legtöbb esetben néhány nap várakozás eredményeket hozhat: a folyadék-, elektrolit- és koagulációs viszonyok rendezése elengedhetetlen. Ha a mútétig néhány hét all rendelkezésre, akkor enteralis, illetve parenterális táplálás állapotú beteg sebásógyulás képessését javítani $(48,49)$.

\section{Mütéti típusok}

Vékonybél "takarékos” mútéti technika A vékonybél kiterjesztett reszekciója rövidbél-szindróma hoz vezethet, amely a beteg hátralévő életét jóvátehe tetlenül károsítja. Vékonybélkímélő mủtéti technikát kel alkalmaznunk. Még bélkonglomerátum esetén is csak a legkárosodottabb belszakaszt tavolyuk el. Ez az eljárás

\section{Stricturoplasztika}

A vékonybél-rendszert áttekintve a szúkült szakaszt identifkáljuk, a legszžkebb szakaszon enterotomít végzünkmajd a vékonybélbe Foley-katétert vezetünk, ballonját $2 \mathrm{~cm}$ átméröre felfújjuk, és a katétert vékonybél-rendszeren áthúzzuk. Ahol a katéter elakad, ott a vékonybelet megjelöljük. Ha a szukuulet $10 \mathrm{~cm}$-nél rovidebb, ott ún. Heineke-Mikulicz-fèle a szükületet hosszirányba behasítjuk, majd harántirányban összevarrjuk, ezzel megszüntetve a szükületet Hosszabb szúkületek esetén $(10 / 20 \mathrm{~cm})$ Finney-féle technikát alkatmazhatunk. Ez az eljárás azt jelenti, hogy a szükült szakasz antimesenterialis oldalát behasítjuk, a belet "U" alakban megtörjük, bélszéleket összevarrjuk, így szüntetjük meg a mzékürlutetet. Ennél hosszabb szúkületek Finney-féle módszerrel történö megoldása nem tanácsos. Ennél hosszabb - 30 vagy $40 \mathrm{~cm}$-es - szúkületek esetén Michelassi módszerét célszerủ alkalmazni. A beavatkozás elvileg egyszerủ, a szǔkült szakaszt hosszirányban megfelezi és széles oldal-az-olda anastomosissal szünteti meg a szúkületet $(51,52)$.

Korábban a plasztikákat csak "beszaradt", fibrotikus, már nem gyulladt szükületek eseten volt tanácsos alkalmazn Ma ez a szemlélet változott, mérsekelt gyulladás esetén is nagy biztonsággal lehet végezni. A plasztikai eljárás során a bélfalból célszerú biopsziát venni az esetleges malignitás kizárása végett.

"Szúk" reszekció

Ha mégis reszekciót kell végezni akkor is csak a legkárosodottabb, gyakorlatilag a megsemmisült bélszakaszt célszerủ eltávolítani. Mesentériumból is csak a minimális szegmenset tanácsos kimetszeni.

Bypassmútét

Evtizedekkel ezelőtt a Crohn-betegség kezelésének általános sebészi megoldása volt a gyulladt bélszakasz megkerülése Ezt ma már csak igen ritkán végezzük, mert a hosszú megke-

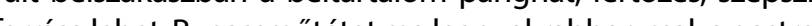

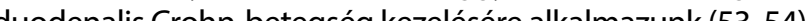

\section{Anastomosis készítése vékonybélen}

Crohn-betegségben

Az emésztőtraktus anastomosisait általában célszerú vég-avég formációban elvégezni. A Crohn-os recidíva leggyakrabban az anastomosis területén jelentkezik, ezért célszerủ tág későobb okozzon passzázszzavart. Ezért pár évvel ezelött széles körben javasolták a széles oldal-az-oldal anastomosist varrógéppel kézzíteni, amely ún funkcionális vég-a-vég anastomo- sis volt (55). Prospektív tanulmányok azonban bizonyították hogy a kézzel készült anastomosis sem rosszabb eredményú, mint a gépi anastomosis. A vég-a-vég anastomosist úgy készlsü el, hogy $2 \mathrm{~cm}$ hosszban hasitsuk be a vekonybel antimesenterialis oldalát mindkét bélvégen igy tolcsérszerú, széUes anastöosist kialakitua. Reszzben hasonló elven készül az készít idoben ajánlott Kono-fele, antimesenterialis oldalon az-olda aźn b́lvéck Értelemszerúen krónikus passzézszavar esetén az orális bélvzakazźny gezen kín pulaz abo lis szakazz öszesiki vég-az-oldalhoz anastomosist készitünk.

eocolicus bélszakasz betegsége

Az ileocoecalis Crohn-betegség a leggyakrabban előforduló okalizáció. Ezen bélszakasz reszekciója jár a legjobb sebészeti sikerrátával. Abban az esetben, ha a bélszakasz szúkülete által okozott passzázszavar a beteg legfőbb panasza, kkor a bélszakasz reszekcióját ideális laparoszkópos úton elvégezni gépi ileocolicus anastomosissal (57). Laparoszkópos beavatkozás ellen szól, ha a bélszakasz a psoas izomzat fele, hasfal felé fisztula-, tályogrendszert képez. Nem eldönmütét során ileocoecalis bélszpendicitis gyanújával akut találjuk, mi a teendő. Biológiai kezelés korszaka elốtt célszerủ volt azonnali reszekciót végezni primer anastomosissal, mert rövid idôn belül ezen betegek egyébként is reszekcióra kerültek (58). Úgy tünik, hogy a reszekciós mütét, laparoszkópos beavatkozás, ebben a lokalizációban is költséghatékonyabb, mint a biológiai terápia.

Vastagbél Crohn-betegség sebészi kezelése Voáboan ortodox szabály volt az, ha a Crohn-betegseg a vastagbel 2/3-at elérte, akkor célszeru total proctocolecvert az esetlegesen visszahagyott vastagbélszakaszban igen nagy valószinúséggel megjelenik (5). Ma ez az allaspont fiatal betegekre való ḱn elfog megaltozott. Hatal betegek esetén alkalmankent elfogadott szegmentális reszekciót végezni. A colon nagykiterjedésú érintettsége esetén colectomiát végzünk a rectum orális szakaszát, illetve a rectosigmoidealis junctiot a hasfalra nyákfisztulának kihozzuk, mint ahogy az akut eseteknél le lett irva (45). A nyakkfisztulán keresztül a rectumcsonk gyógyszerekkel öblithető lesz. Gyógyszeres kezelés után a rectumcsonkra az ileum visszavarrható lesz.

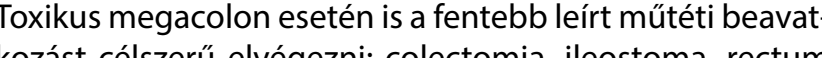
megkímélése nyákfisztulával.

A biológiai kezelés széles kö́ben való elterjedése miatt fiA biólón elhelyése a teljes colont érinto" gyllás écén bízva gy a passzázsból kirekesztett vastagbél reagálni fog a biológiai kezelésre.

miát, azaz perinealis ilealis pouchot Crohn-betegségben általában nem végzünk (60). Néhány ôleg személyes közlés van arról, hogy ha a Crohn-betegség 5-10 éven keresztül a vastagbélen marad és a vékonybelet nem érinti, a pouchképzés elképzelhetó, de a mútét sikeréhez tökéletes múködésủ analis csatorna elengedhetetlen (61). 
Anastomosis készítése vastagbélen Crohn-betegség esetén

Vékony- és vastagbél-anastomosis elkészítésénél gépi oldal-az-oldal anastomosis ajánlott az irodalom szerint, de vaskos, törékeny bélfalak esetén kézi anastomosis a választható eljárás. Vastagbélen a hagyományos mútéti technikát végzünk. lleorectalis anastomosis elkészitése során, mivel a rectum állapota általában nem tookéletes, az elkészítet tehermentesítés céljából draincsövet helyezünk fel.

\section{Hasüregi tályogok kezelése}

A kisméretủ 2-3 cm-es tályogok legtöbb esetben antibiotikum-kezelésre felszivódhatnak. A nagy kiterjedésủ, jól körülhatárolt, hasfalhoz közeli tályogok elsödleges ellátása CT- vagy UH-vezérléssel drenázs (62). Célunk az, hogy a folyamat lokalizációja után, ha szükséges primer reszekciót lehessen elvégezni stomaképzés nélkül. Sajnos, igen gyakran nem jól körülhatárolt tályogot bizonyit a képalkotó vizsgálat. A gyulladásos bélkonglomerátumban az interintestinalis sipolyok következtében tályogrendszer alaku ki, amelyet drenálni megfelelően nem lehet. A tályogrendszer szanálása csak a bélkonglomerátum eltávolításával vagy szétbontásával lehetséges.

\section{Peritonitis kezelése}

Leggyakrabban a vékonybél, illetve a vastagbél durva gyulladása okozza a peritonealis izgalmat, amely aztán hasi fetárást igényel (63). A vastagbélgyulladás kezelése relatíve egyszerübb, mivel a vastagbel reszekciojat szabadabban kezelhetjük, mint a vékonybél eltávolitását. A gondot leg-a többszor a vékonybel több szakaszra terjedó gyulladás okozza. Peritonitises környezetben anastomosist készíten nem tanácsos. Gyakorlatunkban csak a legkárosodottabb bélszakaszt távolítjuk el, a viszonylagosan épnek tủnő bèszakasz orális, illetve aboralis végét a hasfalra kiszájaztatjuk. Ennek a célja kettős: a folyamat, a peritonitis lezajlása után a passzázs helyreállítható, a rövidbél-szindróma pedig elkerülhető. A köztes időben a parenterális tápláláson
kivül az izolált bélszegmenst tápszerrel perfundáljuk, így kívül az izolált bélszegmenst tápszerrel perfundáljuk
csökkentve a parenterális táplálás mennyiségét.

\section{Crohn-os hasi fisztula sebészi kezelése}

A Crohn-betegség minden formájában előfordulhat fisztulaképzódes, amely lehet enteroenteralis, enterocutan, illetcsak a fisztula forrásaként szolgáló bélszakaszt célszerü reszekálni és azt a szervet ahová a Crohn-os bél fisztulizá csak elvarrni, de nem reszekálni (64). Így lehet viszonylag bélkímélő technikával eredményt elérni.

\section{Analis Crohn-betegség kezelése}

A Crohn-betegek 25\%-ánál van valamilyen analis elváltoanalis Crohn-betegség jellemző tünetei: hüvelykuji nag ságúra megnövő lilás, fájdalmas, duzzadt bőrfüggelékek, visszatérő analis-, perianalis tályogok, illetve komplex, akár tóbb külsó és belső nyilással rendelkező fisztularendszer, valtozo mértekú szúkület. Jellemzőek még az analis csatornára, iletve kornyezetére a tômótt indurált szövetek. A sebeszi beavatkozás során alapvetó megfontolás, hogy a crés

\section{Börfüggelék}

A bőrfüggeléket kettő csoportba lehet osztani. A fentebb leirt duzzadt, fájdalmas, vaskos bőrfüggelékek lemetszése nem javasolt, konzervativ terápiát igényelnek (65).

A másik csoportba tartozó, korábbi feltárások vagy nekózisok helyén kialakult fájdalmatlan, piciny bőrhidak átvághatóak azért, hogy az alattuk lévő terület megfelelően tisztítható legyen.

\section{Analis ulcus}

A betegség természetéből kifolyólag az analis csatornán hosszirányban mély behúzódások, bemélyedések keletkezhetnek, roncsolva a szöveti struktúrát (66). A hosszú csatornákon keresztül a híg széklet visszatarthatatlanul kicsúszik. Sebészileg ezt az elváltozást kezelni nehéz, legfeljebb az ereszszerü, alámenő részeket lemetszhetjük, az beteg állapotán. A mély analis ulcusok legtöbbször a rectum gyulladásával járnak együtt.

\section{Analis fissura Crohn-betegségben}

A Crohn-betegek analis fissurája bármely irányban elhelyezkedhet, Igy szokatlanul laterális irányban is észlelhetök fissuràk. A Crohn-betegek analis fissurajara jellemzö legtobb esetben a fajdalmatlanság (67). Sebészi kezeléstöl shincterátmetszéstől óvakodjunk.

\section{Analis tályog Crohn-betegségben}

Az analis tályog, amely szokványos jelenség Crohn-betegeknél, minél hamarabbi, anesztéziában végzett, piciny metszésből történő feltárást igényel. A korai feltárás azért javasolt, hogy a gyulladásos folyamat az amúgy is károsodott sphincter-apparátust tovább ne károsítsa. A feltárást anesztêziában kell elvégezni, így tudjuk legjobban az analis csaMR jelentősen javítja a perianalis feltárás sikerességét.

\section{Perianalis, Crohn-os fisztularendszer}

\section{sebészi kezelése}

A visszatérő tályogképződés megelőzésére ún. drenázs az analis fisztulákon át nem átvágó fonal befüzése, seton behelyezése javasolt A beavatkozás célja nem a fisztula megszüntetése, hanem a lezáródó fisztula esetén kialakuló tályogképződés megakadályozása (68) A fisztularendszer feltérképezéséhez az MR-vizsgálat segítséget adhat de a mütét során a külső járatokba fecskendezett hidrogén-peroxid is a járatrendszert jól kirajzolja. A biológiai kezelés elsődleges alkalmazása perianalis fisztularendszerek kezelése vol

Ep rectum esetén a magasra terjedó fisztulák belső nyilását nyalkahártyalebennyel lehet megkísérelni fedni. Uj terápiás lehetôségként mesenchymalis vagy adipomatosus össejtek lokális injektálásával vannak kedvezö kezdet
eredmények.

\section{Rectovaginalis fisztula}

A rectovaginalis fisztula ellátásában seton-fonál behelyezése segíthet a septumban kialakuló fájdalmas tályogok tya esetén lebennyel megkísérelhető de sajnos a rahírarány magas (69).

\section{Analis strictura}

A Crohn-anus jellemző tulajdonsága szükületre való hajlam. A szükületet általában érdemes mérsékelten feltágítani ( 66 fontos, hogy a szükült, tágított szakaszból rendszeresen biopsziát vegyünk a malignitás kizárása végett.

\section{Tehermentesito stoma szerep}

Vannak olyan esetek, különösen fiatal betegeknél, akiknél a durva anorectalis gyulladás, tartós lázas állapot megfeleló gasztroenterológiai kezeléssel, illetve sphincter izomzatot nem roncsoló sebészeti beavatkozásokkal nem szüntethető meg. Átmeneti tehermentesítő stoma a bete szeptikus állapotát megfelelóen tudja befolyásolni (71). A folyamat megnyugvása után a stomazárás elképzelhetó Tudni kell azonban, hogy a passzázsból kirekesztett analis csatorna föleg biológiai kezelést követően durván beszükülhet, így annak rendszeres tágítása javasolt (72).

\section{Proctectomia}

A betegség jellegéból adódóan az analis csatorna, illetve a rectum olyan fokú gyulladása, szétesése is elöfordulhat amely a záróizom múködését lehetetlenné teszi. llyen eseben nem marad más hátra, mint az anorectum eltávolítása (73). Crohn-betegség esetén ún. intersphinctericus reszek-

\section{$\lambda$ Irodalom}

1. Mao R., Hu PJ. The future of IID therapy: where are we and where should



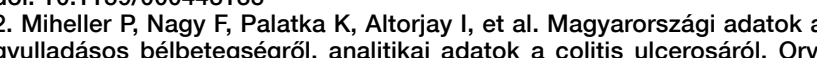

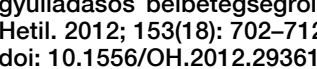

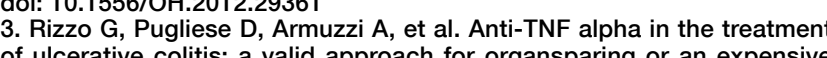

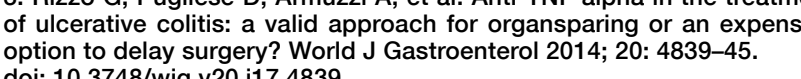

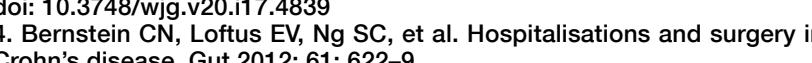

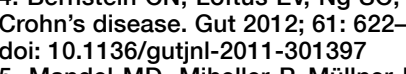



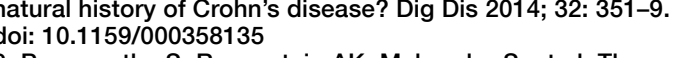



ciót célszerủ elvégezni, amely azt jelenti, hogy a rectumot és az analis nyálkahártyát, a belső záróizomzatot eltávolítjuk, valso zánizomzatot, levalorlemezt osszevarrjuk. Azonban vannak olyan esetek, amikor a kiterjedt perianalis fisztularendszert csak igen széles kimetszéssel lehet eltávolítani, ilyen esetben plasztikai sebészek bevonásával izomlebeny

\section{Laparoszkópia}

A minimál invazív sebészeti eljárás a Crohn-betegségek sebeszetében is teret nyert (74). Laparoszkópos sebész a teljes menybelrendszert, vastagbelet át tudja tekinteni. Teherbélszzasz reszekciója idélis laparoszkópos beocoecalis (57). A bé mobilizálása reszekciója laparoszkóposan történik, az anastomosis készités történhet hason kív̈̈l de történhet intrabdominálisan is varrógépekkel A laparoszkópos beavatkoźs határait a sebész gyakorlottsága határozzómeg. Nagy gyakorlatú sebész recidiv Crohn-betegség mütétjét is vállaljá Áltáában az enterocutan entegovesicalis fisztulák képezik a laparoszkópos sebészet határait.

\section{Következtetések}

Az egyre hatékonyabb gyógyszeres kezelés, a biológiai szerek bevezetése az elmúlt két évtizedben a gyulladásos bélbetegségek sebészetét megváltoztatták. A mútéti igény főeg colitis ulcerosa esetén csökkent, Crohn-betegségben ez még nem érezhető. Elvileg a colitis ulcerosa esetén proctonyezhet. A restorativ proctolectomia perinealis, ilealis rezervoárképzés ileoanalis anastomosissal ma már széles körben általánosan elfogadott eljárás, megfelelö analis funkcionális eredményekkel. Crohn-betegség esetén, mivel a betegséget sem gyógyszeresen, sem sebészileg nem tudjuk megygyógyítani, nagy valószínúséggel több, mint a betegek felénél műtét fog történni. Sőt mi több, a Crohn-betegek negyedében többszörös műtét is indokolt lesz. Ezek alapján vékonybél-reszekciókat takarékos technikával kell elvégeznünk, hogy elkeruiljük a rövidbél-szindróma kialakulását. A magas betegszám, az uj gyógyszerek alkalmazása, a változó selectiszziplináris orvosteam müködését feltételez

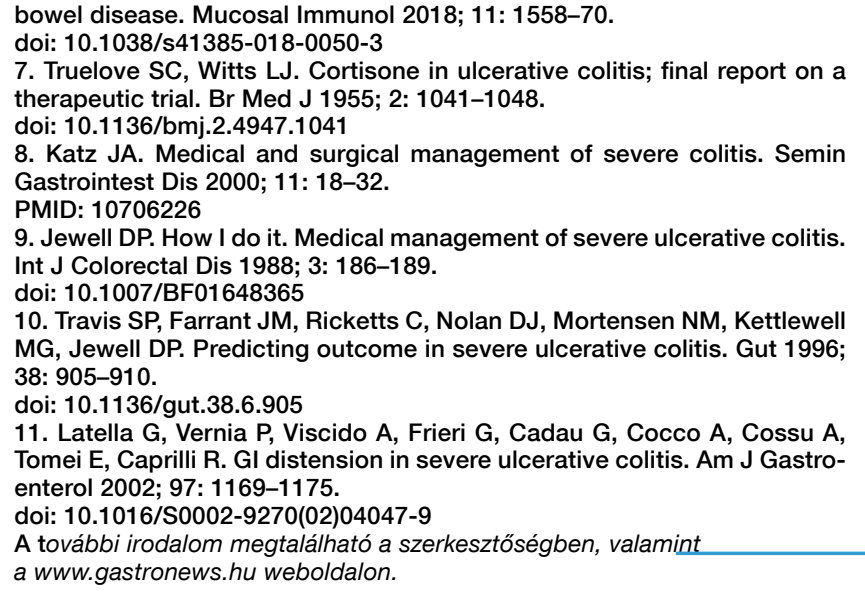

